\title{
Immunomodulation of Nile Tilapia, Oreochromis niloticus, by Nigella sativa and Bacillus subtilis
}

\author{
Ahmad A Elkamel ${ }^{1 *}$ and Gamal M Mosaad ${ }^{2}$ \\ ${ }^{1}$ Fish Diseases and Management, Department of Animal Medicine, Faculty of Veterinary Medicine, Assiut University, Assiut, Egypt \\ ${ }^{2}$ Animal Nutrition, Department of Animal and Clinical Nutrition, Faculty of Veterinary Medicine, Assiut University, Assiut, Egypt
}

\begin{abstract}
The aim of this study is to investigate the modulation of the immune system of Nile tilapia, Oreochromis niloticus by the black cumin seeds, Nigella sativa, or Bacillus subtilis PB6 (CloSTAT) as feed additives. Four diet regimes, a basic (control), CloSTAT, nigella, or combination of the black cumin seeds and CloSTAT were formulated and used to feed fish for 30 successive days. Half of the fish were used to investigate some of the immune parameters as serum globulins, white blood cell counts, and phagocytic activities and phagocytic indices. The other half of fish was subjected to infection challenge with Aeromonas hydrophila to investigate the disease resistance ability of the fish received the feeding additives. Results showed that the serum globulins have significantly increased in fish received the combination diet, while white blood cells have significantly increased in fish fed with nigella or combination ration. Phagocytic activities and indices of the fish fed the combination ration were significantly higher than those of the control groups. The mortality rate of fish fed with nigella or combination ration and challenged with $A$. hydrophila were significantly lower than those that received the basic diet. The current study clearly demonstrated that black cumin, CloSTAT or both can be used to modulate the immune system of Nile tilapia to the favour of resistance to diseases.
\end{abstract}

Keywords: Nile tilapia; Probiotic; Nigella Sativa; Immunomodulation

\section{Introduction}

Currently, Egypt is one of the countries where aquaculture is growing fastest with Nile tilapia, Oreochromis niloticus, is the most widely farmed species [1]. Unfortunately, intensive aqua-farming is accompanied by several problems where infectious diseases come first in limiting the production with consequent negative impact on growth, fecundity and productivity. The use of antibiotics and chemotherapy was the method of choice as the disease control strategy; however, the abuse of chemotherapeutics, especially antibiotics has resulted in development of multiple antibiotic resistant bacteria [2]

Defense system of fish is very important against microorganisms, therefore, using organic, inorganic, or synthetic matters as immunostimulant has been used as a better alternative to antibiotics to control fish diseases $[3,4]$. Hence, in the last decade there has been increasing interest in the modulation of the non-specific immune system of fish as both treatment and prophylactic measures against diseases [5].

Prepared diets not only provide the essential nutrients that are required for normal physiological functioning, but also may serve as a medium by which fish can receive other components that may affect their health [6]. Feed additives such as probiotics or medicinal plants enhance not only the growth rate, but also can positively stimulate the non-specific defense mechanisms of fish. Bacillus spp. may modulate the mucosal immune systems enhancing their resistance to enteric pathogens and so improved survival and growth of tilapia $[7,8]$. Black cumin, Nigella sativa, an annual herb that belongs to the botanical family of Ranuculaceae, showed antibacterial fungicidal effects [9]. Black cumin seeds have been used as enhancer for performance, growth and immune system of some fish species [10,11].

Therefore, the aim of the present study is to investigate the immunomodulation effects of black cumin seeds, N. sativa, or Bacillus subtilis PB6 (CloSTAT) as feed additives for Nile tilapia, O. niloticus. The influence of such additives on the immune hematologic parameters, non-specific immune response of Nile tilapia, and their diseases resistance abilities will be evaluated.

\section{Materials and Methods}

\section{Fish}

Alive Nile tilapia, $O$. niloticus, with an average body weight of 40 $\pm 5 \mathrm{~g}$ were obtained from a private fish farm at Assiut Governorate and transported to the Aquatic Animals Wet Lab., Veterinary Clinical Hospital, Faculty of Veterinary Medicine, Assiut University. Fish were housed in $500 \mathrm{~L}$ tanks with dissolved oxygen of $5.5 \pm 0.2 \mathrm{mg} / \mathrm{L}$. Prior to the experiment, apparently healthy fish were acclimated for 2 weeks in $100 \mathrm{~L}$ glass aquaria according to the protocol of maintaining bioassay fish as was previously described [12].

\section{Diets and feed additives}

Four different diets with or without additives, representing four diet variants, were formulated to be used for feeding of fish. A basic diet (control) was formulated of grounded yellow corn (34.9\%), soya bean meal (28.6\%), fish meal (17.0\%), wheat bran (9.3\%), vegetable oils (6.5\%), ground lime stone $(0.70 \%)$, bone meal $(0.30 \%)$, mineral mixture (1.7\%) and vitamin mixture (1.0\%). The three other experimental diets were formulated as a CloSTAT diet (basic diet with $0.04 \%$ of CloSTAT), a nigella diet (basic diet with $3.0 \%$ of $N$. sativa), and a combination diet (basic diet with $0.04 \%$ CloSTAT and $3.0 \%$ N. sativa).

\section{Experimental design}

Two hundreds and ten acclimated Nile tilapia were used to conduct this study in three replicates. Fish were randomly divided among

*Corresponding author: Elkamel AA, Department of Animal Medicine, Faculty of
Veterinary Medicine, Assiut University, Assiut , Egypt, E-mail: aelkamel@aun.edu.eg Received July 02, 2012; Accepted August 16, 2012; Published August 26, 2012

Citation: Elkamel AA, Mosaad GM (2012) Immunomodulation of Nile Tilapia, Oreochromis niloticus, by Nigella sativa and Bacillus subtilis. J Aquacult Res Dev 3:147 doi:10.4172/2155-9546.1000147

Copyright: (c) 2012 Elkamel AA, et al. This is an open-access article distributed under the terms of the Creative Commons Attribution License, which permits unrestricted use, distribution, and reproduction in any medium, provided the original author and source are credited. 
replicates into sets and groups. Each replicate included two sets, where one set was used for evaluating the immune blood parameters of fish (blood set), while the other set was used for the challenge experiment (challenge set). Each blood set had four equal experimental groups that represent the 4 nutritional treatments (corresponding to the 4 diet variants). Thus, a control group received the basic diet, the second group received the CloSTAT diet, the third group received the nigella diet, while the fourth group received the combination diet. While each challenge set had the same four groups as the blood set and assigned as challenge groups. Each challenge set had 2 additional groups assigned as challenge control groups that received the basic diet and remained unchallenged as a control for the challenge experiment. Each group had 7 fish and was fed ad libitum with only one diet variant twice daily for 30 successive days.

A total of 30 glass aquaria of $100 \mathrm{~L}$ capacity were used to conduct this study. Throughout the experiment, the temperature was maintained at $24^{\circ} \mathrm{C}$ and the dissolved oxygen level at $6.0-7.0 \mathrm{mg} / \mathrm{L}$, while the $\mathrm{pH}$ levels were 7.2-7.5.

\section{Haematological studies}

By the end of the feeding experiment, fish of all groups of the blood sets were anesthetized using tricaine methanesulfonate (MS-222, Argent Chemical Labs, Redmond, Washington, USA). Blood samples were collected from the caudal vein of fish and were divided into two portions. One part was collected with $3 \%$ sodium citrate and used for white blood cells count or mixed with Candida albicans culture to assess phagocytic activity. The second portion of the blood sample was allowed to clot overnight at $4^{\circ} \mathrm{C}$, centrifuged at $3000 \mathrm{xg}$ for $15 \mathrm{~min}$ and non-hemolysed serum was collected and stored at $-20^{\circ} \mathrm{C}$ until use.

White blood cells (WBCs) were counted using the Neubauer haemocytometer (Boeckel Co., Hamburg, Germany), in Natt-Herrick diluents [13]. Levels of serum total protein and albumin were measured using spectrophotometry and "Total Protein" and "Albumin" kits (Spectrum, Egyptian Company for Biotechnology, Obour City, Cairo, Egypt).

Globulin levels were determined by direct subtracting the values of the albumin from those of the total protein.

\section{Phagocytosis assay}

Phagocytic activity (PA) was estimated as previously described [14]. Briefly, $200 \mu \mathrm{l}$ of each blood sample collected from fish were mixed with $10 \mathrm{mg}$ of C. albicans culture in eppendorf, shaken and incubated $25^{\circ} \mathrm{C}$ for 4 hours. After incubation, smears of the blood samples were made, fixed, and stained with Giemsa stain. Phagocytic activities were estimated by calculating the proportions of macrophages with intracellular yeast cells by random count of 300 macrophages and expressed as percentages. The phagocytic indices (PI) were estimated by calculating the average number of yeast cells per one macrophage.

\section{Experimental challenge}

Bacterial strain: An A. hydrophila strain (AH5) was isolated from a clinical case of infected fish during a mass mortality in a local farm of Nile tilapia showing signs of septicemia. The strain was identified by Gram stain, motility test, and various biochemical characters [15], and preserved $-80^{\circ} \mathrm{C}$. The A. hydrophila $\mathrm{AH} 5$ strain was passed three times in Nile tilapia through intraperitoneal injection before using for experimental challenge.

Bacterial challenge suspension and counts: Colony forming units (cfu) counts in bacterial suspensions were determined using spectrophometery optical density values at wavelength of $600 \mathrm{~nm}$ and standard-plate-count method with ten-fold serial dilution [16]. Counts were determined on brain heart infusion (BHI) agar plates. The challenge suspension was prepared by growing the $\mathrm{AH} 5$ strain in $\mathrm{BHI}$ broth at $25^{\circ} \mathrm{C}$ until log phase (optical density of 1.6 that is equivalent to $\left.6.0 \times 10^{9} \mathrm{cfu} / \mathrm{ml}\right)$.

Experimental infection: The four challenge groups of each challenge set were challenged through immersion in $1.0 \times 10^{7} \mathrm{cfu} / \mathrm{ml}$ of AH5 for $30 \mathrm{~min}$ in a volume of $30 \mathrm{~L}$. One of the challenged control groups of each set was subjected to sterile BHI broth for the same duration (30 $\mathrm{min}$ ), while the other group remained unchallenged. Mortalities were recorded daily till no mortalities were recorded for three successive days for a given treatment. Re-isolation and identification of bacteria was done from freshly dead fish as mentioned above.

\section{Statistical analysis}

The experimental design was completely randomized. Data were analyzed by analysis of variance (ANOVA) using the general linear models (GLM) procedure [17]. The overall model was tested for significance at $\mathrm{p}<0.05$. Duncan's multiple range test was used for pair wise comparison of means of the various treatments.

\section{Results}

Results of the current study showed that the WBCs of Nile tilapia fed on the combination diet were significantly higher than those of fish fed on any other diets, while WBCs of fish fed on nigella diets showed a significant increase than that of the control (Table 1). Serum globulins of Nile tilapia fed on the combination ration were higher than those of all other groups, and significantly higher than those of fish fed on the basic ration (Table 1). Phagocytic activity of Nile tilapia phagocytes received the nigella or the combination diets were significantly higher than the other two groups, while the phagocytic index of only Nile tilapia received the combination diet was significantly higher than those of all other groups (Table 1). Cumulative mortalities of Nile tilapia challenged with $A$. hydrophila were significantly less in fish fed on nigella or combination diets than those of fish fed on the basic or CloSTAT diets (Table 1).

\section{Discussion}

The aim of the present study was to investigate the effect of dietary supplementation of black cumin and/or Bacillus subtilis PB6 (CloSTAT) on the immune response and diseases resistance of cultured Nile tilapia. One of the most effective methods of controlling diseases in aquaculture is strengthening the defense mechanisms of fish through prophylactic administration of immunostimulants $[18,19]$.

\begin{tabular}{|l|l|l|l|l|}
\hline & Basic (Control) & CloSTAT & Nigella & Combination \\
\hline WBCs & $36.2 \pm 3.86^{\mathrm{a}}$ & $39.41 \pm 4.78^{\mathrm{ab}}$ & $40.22 \pm 4.41^{\mathrm{b}}$ & $44.53 \pm 5.11^{\mathrm{c}}$ \\
\hline Globulin (g/dl) & $4.18 \pm 1.01^{\mathrm{a}}$ & $4.63 \pm 1.20^{\mathrm{ab}}$ & $4.88 \pm 1.74^{\mathrm{ab}}$ & $5.89 \pm 1.05^{\mathrm{b}}$ \\
\hline Phagocytic activity & $24.4 \pm 2.10^{\mathrm{a}}$ & $26.20 \pm 1.89^{\mathrm{a}}$ & $30.74 \pm 2.33^{\mathrm{b}}$ & $37.35 \pm 3.21^{\mathrm{c}}$ \\
\hline Phagocytic index & $1.01 \pm 0.02^{\mathrm{a}}$ & $1.02 \pm 0.12^{\mathrm{a}}$ & $1.09 \pm 0.25^{\mathrm{ab}}$ & $1.21 \pm 0.47^{\mathrm{b}}$ \\
\hline $\begin{array}{l}\text { Cumulative Mortal- } \\
\text { ity percent }\end{array}$ & $71.42 \pm 11.6^{\mathrm{a}}$ & $57.14 \pm 11.6^{\mathrm{ab}}$ & $47.61 \pm 6.73^{\mathrm{b}}$ & $23.80 \pm 6.73^{\mathrm{c}}$ \\
\hline
\end{tabular}

Table 1: Effect of four diet regimes, basic (no additives), CloSTAT diet (basic diet with $0.04 \%$ of CloSTAT), a nigella diet (basic diet with $3.0 \%$ of Nigella sativa), and a combination diet (basic diet with $0.04 \%$ CloSTAT and $3.0 \%$ Nigella sativa) used to feed Nile tilapia, Oreochromis niloticus, on the white blood cells (WBCs) count globulin level, phagocytic activity, phagocytic index, and cumulative mortality percent of fish challenged with Aeromonas hydrophila. Data represent the average of 3 experiments. Means of the same raw with the same letter are not significantly different, while those with different letters are significantly different $(p<0.05)$. 
Natural immunostimulants are considered promising alternatives to chemotherapy and vaccines because of their broad spectrum activity, cost effectiveness, and eco-friendly measures [20].

In the current study, the immuno-potentiation effects of black cumin and/or CloSTAT were investigated after 30 days of successive dietary supplementation of Nile tilapia. In fish, most of the beneficial effects of dietary supplementation of medicinal herbs or probiotics as weight gain, improved immunity, and disease resistance have been recorded within a feeding regime of 1-10 weeks [21,22]. The time course for optimum induction of immune response differs with respect to probiotic strain, type of medicinal plant, and type of the immune parameter [21].

The innate immune system of fish is the first line and primitive of defense against invading pathogens. The major components of the immune system are macrophages, monocytes, granulocytes, and humoral elements, such as lysozymes, immunoglobulins and the complement system $[23,24]$.

White blood cells (WBCs) of fish play a crucial role in the cellular immunity and resistance to infectious diseases [25]. The significant increases in WBCs counts in fish fed with the nigella or combination diets may be due to the activation of the hemopoietic tissues either by the black cumin [26] or B. subtilis [27]. Several types of leukocytes participate in the cellular immune response, including lymphocytes, monocytes, granulocytes (neutrophils, eosinophils and basophils), and cytotoxic cells [28]. On the other hand, leukocyte functions can be improved by natural immunostimulants as was previously reported in gold fish that were supplemented with mixtures of chosen herbs incorporated in shrimp and fish diet [22]. In addition, recent studies indicated that probiotics can stimulate the piscine gut associated lymphoid tissue provoking an immune response [21].

As a first line of defense, various peptides such as lysozyme, antibodies, complement factors and other lytic factors are present in serum where they prevent adherence and colonization of microorganisms leading to prevention of infections and disease [29]. In the current study, levels of the serum immunoglobulin of fish significantly increased by dietary supplementation with CloSTAT and black cumin in the combination ration. This increase in serum antibodies provides immediate and broad protection against bacterial and viral pathogens [25]. Certain herbal immunostimulants have been reported to increase total protein as well as total globulin in fish [30]. The total immune-globulin levels were significantly higher in rainbow trout, Oncorhynchus mykiss, fed with black cumin diet than the control groups [31]. Carp, Cyprinus carpio, total serum protein and globulin content were markedly increased after oral administration of Aloe vera compared to the controls [32]. Previous studies revealed that probiotic bacteria could stimulate the immunoglobulins production in fish [33]. Serum IgM levels of fish fed Baciilus pumilus or Bacillus clausiicontaining diets were higher than that of control fish after 30 days of feeding [34].

Phagocytosis is a primary, non-specific defense mechanism against invasion of pathogenic organisms of hosts [35]. In the current study, Nile tilapia phagocytes showed increased the phagocytic activities and indices when fed on either black cumin or combination diets. The enhancement of phagocyte function is one of the most immediate and key effects produced by probiotics [36] and plant extracts [37] on the host immune system of fish. Previous studies demonstrated that aquatic animals fed probiotic had significantly increased phagocytic activity and index [38,39]. In addition, extracts of four Chinese herbs increased the phagocytosis activities of crucian carp white blood cells [40].

In this study, stimulation of the immune system of Nile tilapia as a result of feeding of black cumin or combination diets have positively impacted the resistance of fish to A. hydrophila infection as was indicated by the significantly lower mortality rates of fish challenged with virulent $A$. hydrophila. It was reported that Ocimum sanctum enhanced the disease resistance in Oreochromis mossambicus against $A$. hydrophila infections [41]. Furthermore, Nile tilapia fed with probiotics and challenged with $A$. hydrophila showed significant decrease in mortalities [42].

Results of the current study proved that dietary supplementation of CloSTAT, black cumin, or combination of the two enhanced the overall immune response of Nile tilapia as was indicated by the significant increase of the WBC numbers, globulin proteins and the phagocytic activities of fish phagocytes. This modulation of the fish immunity has greatly enhanced the resistance of challenged fish to A. hydrophila as was indicated by the significant decrease in mortalities in fish received the nigella or combination diets.

\section{References}

1. FAO (2005) - Vol. 96/2. Food and Agriculture organization of the United Nations, Rome, Italy.

2. Gyles CL, Palchaudhuri S, Maas WK (1977) Naturally occurring plasmid carrying genes for enterotoxin production and drug resistance. Science 198 198-199.

3. Findlay VL, Munday BL (2000) The immunomodulatory effects of levamisole on the nonspecific immune system of Atlantic salmon (Salmo salar L) J Fish Diseas 23: 369-378.

4. Cuesta A, Meseguer J, Esteban MA (2004) Total serum immunoglobulin M levels are affected by immunomodulators in Seabream (Sparus aurata L.). Vet Immunol Immunopathol 101: 203-210.

5. Misra CK, Das BK, Mukherjee SC, Meher PK (2006) The immunomodulatory effects of tuftsin on the non-specific immune system of Indian Major carp (Labeo rohita). Fish Shellfish Immunol 20: 728-738.

6. Gatlin DM III (2002) Nutrition and fish health. In: Fish Nutrition (Halver JE Hardy RW) (eds). Academic Press, San Diego, CA, USA, 671-702.

7. Gullian M, Thompson F, Rodriguez J (2004) Selection of probiotic bacteria and study of their immunostimulatory effect in Penaeus vannamei. Aquaculture 233 $1-14$.

8. Eid AH, Mohamed KA (2008) Effect of using probiotic as growth promoters in commercial diets for mono sex Nile tilapia (Oreochromis niloticus) fingerlings. 8th international symposium of tilapia in aquaculture. 241-253.

9. Akgul A (1989) Antimicrobial activity of black cumin (Nigella sativa L) essential oil. Gazi Journal of Faculty of Pharmacology 6: 63-68.

10. Abdel-Ghaffar FA, El-Feki MA, Faheem HI, Gad MA (2003) Potentiating effects of some natural products on the common carp immune system against Aeromonas hydrophila. J Aquat Biol Fish 7: 23-47.

11. Diab AS, Aly SM, John G, Abde-Hadi Y, Mohammed MF (2008) Effect of garlic, black seed and Biogen as immunostimulants on the growth and survival of Nile tilapia, Oreochromis niloticus (Teleostei: Cichlidae) and their response to artificial infection with Pseudomonas fluorescens. Afr J Aqu Sci 33: 63-68.

12. Ellsaesser CF, Clem LW (1986) Hematological and immunological changes in channel catfish stressed by handing and transport. J fish biol 28: 511-521.

13. Natt MP, Herrick CA (1952) A new blood diluent for counting the erythrocytes and leucocytes of the chicken. Poult Sci 31: 735-738.

14. Kwahara E, Ueda T, Nomura S (1991) In vitro phagocytic activity of white spotted shark cells after injection with Aeromonas salmonicida extracelluar products. Fish Pathology 26: 213-214.

15. Austin B, Austin D (2007) Bacterial fish pathogens disease of farmed and wild fish. Dordrecht; Chichester: Springer; Published in association with PRAXIS Pub Ltd. 
Citation: Elkamel AA, Mosaad GM (2012) Immunomodulation of Nile Tilapia, Oreochromis niloticus, by Nigella sativa and Bacillus subtilis. J Aquacult Res Dev 3:147 doi:10.4172/2155-9546.1000147

Page 4 of 4

16. Elkamel AA, Thune RL (2003) Invasion and replication of Photobacterium damselae subsp. piscicida in fish cell lines. J Aqua Ani Hea15: 167-174.

17. SAS II (1999) SAS/STAT ${ }^{\circledR}$ User's Guide, Version 8. Cary, NC: SAS Institute Inc, USA.

18. Robertsen B (1999) Modulation of the non-specific defence of fish by structurally conserved microbial polymers. Fish Shellfish Immunol 9: 269-290.

19. Raa J (1996) The use of immunostimulatory substances in fish and shellfish farming. Reviews in Fisheries Science 4: 229-288.

20. Anderson DP (1992) Immunostimulants, adjuvants, and vaccine carriers in fish application to aquaculture. Annual Review of Fish Diseases 2: 281-307.

21. Nayak SK (2010) Probiotics and immunity: A fish perspective. Fish Shellfish Immunol 29: 2-14.

22. Harikrishnan R, Balasundaram C, Heo MS (2010) Herbal supplementation diets on hematology and innate immunity in goldfish against Aeromonas hydrophila. Fish Shellfish Immunol 28: 354-361.

23. Magnadóttir B (2006) Innate immunity of fish (overview). Fish Shellfish Immuno 20: $137-151$

24. Secombes CJ, Fletcher TC (1992) The role of phagocytes in the protective mechanisms of fish. Annual Review of Fish Diseases 2: 53-71.

25. Whyte SK (2007) The innate immune response of finfish--a review of current knowledge. Fish Shellfish Immunol 23: 1127-1151.

26. Nair SC, Salomi MJ, Panikkar B, Panikkar KR (1991) Modulatory effects of Crocus sativus and Nigella sativa extracts on cisplatin-induced toxicity in mice. J Ethnopharmacol 31: 75-83.

27. Kumar R, Mukherjee SC, Prasad KP, Pal AK (2006) Evaluation of Bacillus subtilis as a probiotic to Indian major carp, Labeo rohita (Ham.). Aquaculture Research 37: 1215-1221.

28. Nakanishi T, Aoyagi K, Xia C, Dijkstra JM, Ototake M (1999) Specific cellmediated immunity in fish. Vet Immunol Immunopathol 72: 101-109.

29. Alexander JB, Ingram GA (1992) Noncellular non-specific defence mechanisms of fish. Annual Review of Fish Diseases 2: 249-279.

30. Rao YV, Romesh M, Singh A, Chakrabarti R (2004) Potentiation of antibody production in Indian major carp Labeo rohita, rohu, by Achyranthes aspera as a herbal feed ingredient. Aquaculture 238: 67-73.

31. Dorucu M, Colak SO, Ispir U, Altinterim B, Celayir Y (2009) The Effect of Black
Cumin Seeds, Nigella sativa, on the Immune Response of Rainbow Trout, Oncorhynchus mykiss. Mediterranean Aquaculture Journal 2: 27-33.

32. Alishahi M, Ranjbar MM, Ghorbanpoor M, Peyghan R, Mesbah M, et al. (2010) Effects of dietary Aloe vera on some specific and nonspecific immunity in the common carp (Cyprinus carpio). Iran J Vet Res 4: 189-195.

33. Nayak SK, Swain P, Mukherjee SC (2007) Effect of dietary supplementation of probiotic and vitamin $\mathrm{C}$ on the immune response of Indian major carp, Labeo rohita (Ham.). Fish Shellfish Immunol 23: 892-896.

34. Sun YZ, Yang HL, Ma RL, Lin WY (2010) Probiotic applications of two dominant gut Bacillus strains with antagonistic activity improved the growth performance and immune responses of grouper Epinephelus coioides. Fish Shellfish Immunol 29: 803-809.

35. Olivier G, Eaton CA, Campbel N (1988) Interaction between Aeromonas salmonicida and peritoneal macrophage of Brook trout Salíelinus fontinalis. Vet Immunol Immunop 12: 223-234

36. Zhang Q, Ma H, Mai K, Zhang W, Liufu Z, et al. (2010) Interaction of dietary Bacillus subtilis and fructooligosaccharide on the growth performance, nonspecific immunity of sea cucumber, Apostichopus japonicus. Fish Shellfish Immunol 29: 204-211.

37. Dügenci SK, Arda N, Candan A (2003) Some medicinal plants as immunostimulant for fish. J Ethnopharmacol 88: 99-106.

38. Dias DdC, De Stefani MVD, Ferreira CM, Franca FM, Ranzani-Paiva MJT, et al. (2010) Haematologic and immunologic parameters of bullfrogs, Lithobates catesbeianus, fed probiotics. Aquac Res 41: 1064-1071.

39. Harikrishnan R, Balasundaram C, Heo MS (2010) Effect of probiotics enriched diet on Paralichthys olivaceus infected with lymphocystis disease virus (LCDV). Fish Shellfish Immunol 29: 868-874.

40. Yin G, Ardo L, Jeney Z, Xu P, Jeney G (2008) Chinese herbs (Lonicera japonica and Ganoderma lucidum) enhance non-specific immune response of tilapia, Oreochromis niloticus, and protection against Aeromonas hydrophila. Diseases in Asian Aquaculture VI, Fish Health Section, Asian Fisheries Society, Manila, Philippines, 269-282.

41. Logambal SM, Michael RD (2000) Immunostimulatory effect of Azadirachtin in Oreochromis mossambicus (Peters). Indian J Exp Biol 38: 1092-1096.

42. Ali HM, Ghazalah AA, Gehad EA, Hammouda YA, Abo-State HA (2010) Practica Aspects and Immune response of Probiotics Preparations Supplemented to Nile Tilapia (Oreochromis Niloticus) Diets. Nature and Science 8: 39-45. 